\title{
Contributions from Culture to Sustainable Territorial Development
}

\author{
Verônica Nascimento Brito Antunes* \\ Institute of Social and Applied Sciences, Federal Rural University of Rio de Janeiro, Brazil.
}

Submission: February 28, 2019; Published: March 11, 2019

*Corresponding author: Verônica Nascimento Brito Antunes, Institute of Social and Applied Sciences, Federal Rural University of Rio de Janeiro, 23897-000 Seropédica, Rio de Janeiro, Brazil

\begin{abstract}
It is intended to present a preliminary analysis of the contributions of cultural anthropology to sustainable territorial development (STD) under two aspects: cultural diversity creates development opportunities insofar as they generate economic, social and environmental advantages and, the valorization of the symbolic and intangible resources present in a territory that values dynamics capable of promoting progress. Initially, this short essay discusses notions of territory and sustainability.
\end{abstract}

Keywords: Cultural diversity; Territorial development; Cultural heritage; Symbolic resources; Environment; Sustainable development

\section{Mini Review}

At the International Conference on Conservation and Development (IUCN) held in Canada in 1986, the concept of Sustainable and Equitable Development was presented as a new model with the following principles: conservation of the integrated environment the development of basic human needs, the achievement of equity and social justice, the pursuit of social self-determination and cultural diversity, and the maintenance of ecological integrity. Reinforcing the dynamism of sustainability, it is emphasized that society and the environment are constantly changing, as are technologies, culture, values and aspirations. Everything is constantly transformed and therefore a society must truly allow and sustain such modifications [1]. It is pertinent to consider the notion of sustainability. One issue that has a decisive influence on the conception and dissemination of what is becoming sustainability is the world view of those involved, considering that the sustainability approach is explored in several fields of knowledge [2].

Thus, another source of influence to form the concept of sustainability are institutional visions and conceptions.In this perspective, groups can be identified that influenced the construction and dissemination of the concept of sustainability, such as: World Commission on Environment and Development [3]- Report Our Common Future; International Institute of Environment and Development [4]. In addressing the concepts of "Eco-development" and "Sustainable Development" as synonyms, it is assumed that all development-oriented planning needs to simultaneously take into account five dimensions of sustainability [5]:

a. social (combating poverty and building a civilization with greater equity in the distribution of income, in order to reduce the gap between the living standards of the rich and the poor).

b. economic (economic efficiency must be evaluated in macro-social terms, not only through the criterion of corporate profitability, aiming at promoting structural changes that act as stimulators of human development without compromising the environment).

c. ecological (related to the preservation of natural resources as a basis for biodiversity) proposes a more efficient production system with ecologically correct and economically viable solutions through the use of clean technologies and renewable alternative energy sources, as well as the definition of norms for an adequate environmental protection).

d. spatial or geographic (geared towards a balanced urban-rural configuration, better territorial distribution of urban settlements and economic activities) and 
e. cultural (referring to respect for cultural specificities, identities and traditions of local communities, valuing the continuity of traditions and plurality of peoples).

Years later, the author [6] expands the approach to sustainable development by introducing three different dimensions that can be analyzed in a related way:

a. Environmental (encompasses respect for the capacity of self-purification of natural ecosystems).

b. National policy (involves democracy, a reasonable level of social cohesion, human rights and development of the State's capacity to implement the National project in partnership with all entrepreneurs).

c. International policy (based on the promotion of peace and international cooperation, international financial control, application of the Precautionary Principle in the management of the environment and natural resources protection of biological and cultural diversity and scientific and technological cooperation).

It is possible to add two other dimensions: the political dimension that refers to the creation of conditions that allow effective participation in the planning and social control of public policies by civil society; and the technological dimension which concerns the promotion of local scientific and technological development [7]. Covering the psychological, social and cultural dimensions, the practice of environmental education is emphasized, based on the need to understand culture and achieve individual well-being, as constituent elements of sustainable development $[8,9]$. Despite all the efforts undertaken in understanding and characterizing the most diverse dimensions of sustainability, what has prevailed in studies on sustainable development is the tripod involving environmental, social and economic dimensions. Of these three fundamental components, the well-known triple bottom line arises, in which society seeks the balance between what is "socially desirable, economically viable and ecologically sustainable" [10]. Most importantly, in addressing the three dimensions of business sustainability, it is the dynamic balance between the economic, social and environmental dimensions. It should be noted that the concept of sustainable development includes multidimensionality that includes more than the economic, social and environmental dimensions often mentioned in the studies on the subject. Based on this orientation, the importance of incorporating the cultural dimension is clearly perceptible.

Reflecting on the challenges of development, the need to highlight the dynamics that enhance the effectiveness of non-market relations between men is emphasized, in order to value the wealth they have, while proposing to strengthen the perspective [11]. In this way, "territorial development means any process of mobilization of actors that leads to the elaboration of a strategy of adaptation to external limits, on the basis of a collective identification with a culture and a territory" [12]. The perspective of sustainable territorial development "is not limited to the search for optimization of the factors of production for economic growth [13]. In this case, the different resources (material and symbolic, monetary and non-monetary) of a territory are not only sources of comparative advantages, but are "seen as an expression of a natural and cultural heritage shared by the populations" and therefore need be managed and used with ecological prudence. "The concept of patrimonial resource allows to deepen the reflection on the ecological, social and political sustainability of the territorial dynamics of development" [14].

The STD approach thus opens up new analytical and methodological perspectives in terms of public management and planning, bringing to light new institutional arrangements that can be used: the analysis and consideration of specificities and heritage resources (both natural and cultural) in development processes. It should be added that such cultural perspective is associated with path dependence, that is, a particular conception of historical development linked to a social causality dependent on the trajectory traversed.A redirection in the focus of research on the determinants of development over time is no longer based on 'fundamentalism of capital', but ultimately on the role of institutions. However, the new paradigm of development, termed by the author of "institutional turnaround", is accompanied by a certain tendency to standardize policies and reproduce institutional arrangements recommended by the international establishment. The main expression of the 'upset' is the phenomenon that classifies as 'institutional monoculture': "it is based both on the general premise that institutional efficiency does not depend on adaptation to the local socio-cultural environment, but on the more specific premise that idealized versions of Anglo-American institutions are ideal development tools regardless of the level of development or position in the global economy"[15]. The argument is reinforced by Chang in denouncing the pressure exerted by developed countries and international bodies to adopt an agenda of 'good policies' and 'good institutions' for governance by developing countries [16].

In this sense, recognition of the cultural diversity of a territory is a key element for rethinking progress from a perspective that goes beyond economic growth, but rather privileges the different resources (material and symbolic) as sources of territorial dynamics. Especially the immaterial cultural heritage, for example, revealed by the records of numerous manifestations of knowledge, celebrations, forms of expression, places and buildings, created and recreated by social groups, reveal the interaction with nature and history, with a view to preservation of the identity and continuity of human evolution and diversity. For these reasons, this research intends to discuss these aspects of immaterial cultural as strategies of development [17]. 


\section{References}

1. Bossel H (1998) Earth at a crossroads: paths to a sustainable future. Cambridge University Press, Cambridge, UK.

2. VINHA V (1999) A convenção do desenvolvimento sustentável e as empresas eco-comprometidas. Doctoral Thesis - Post-Graduation in Desenvolvimento, Agricultura e Sociedade, Instituto de Ciências Humanas e Sociais, Federal Rural University of Rio de Janeiro, Rio de Janeiro, pp. 291.

3. WCED (1987) Our common Future. Oxford University Press, Oxford, UK.

4. IIED (2001)

5. Sachs (1993) Estratégias de transição para o século XXI desenvolvimento e meio ambiente. São Paulo: Studio Nobel/Fundap, 1993.

6. Sachs I (2000) Caminhos para o desenvolvimento sustentável. Editora Garamond.

7. Lage A, Barbieri J (2001) Avaliação de projeos para o desenvolvimento sustentável: uma análise do projeto de energia eólica do Estado do Ceará, com base nas dimensões da sustentabilidade. In: Anais Enanpad 2001, Campinas, Brazil.

8. Marrul Filho S (2000) Do desenvolvimento para além do desenvolvimento. In: Quintas JS (org.). Pensando e praticando a educação ambiental na gestão do meio ambiente. Brasília: IBAMA.
9. Jacobi P (2003) Educação ambiental, cidadania e sustentabilidade. Cadernos de Pesquisa,118: 189-205.

10. Elkington J (1999) Elkington, John. Cannibals with Forks - The Tipple Bottom Line of $21^{\text {st }}$ Century Business. Capstone.

11. Pecqueur B (2000) Qualite et développement - L'hypothese du panier de biens. In: Symposium sur le développement regional. INRA-DADP. Montpellier, France.

12. Pecquer B (2005) O desenvolvimento territorial: uma abordagem dos processos de desenvolvimento para as economias do Sul. In: Raízes, 24(1-2):10-22.

13. Vieira, Cazella e Cerdan (2006) p.15.

14.Andion C (2009) Contribuições do debate sobre desenvolvimento territorial sustentável para a efetividade da gestão municipal. Política \& Sociedade 14:182-209.

15. Evans P (2003) Além da "Monocultura Institucional": instituições, capacidades e o desenvolvimento deliberativo. Sociologias, 5(9): 2062.

16. Chang (2004) Chutando a escada: estratégias do desenvolvimento um uma perspectiva histórica, editora UNESP.

17. Antunes V, Silva J, Brito M (2018) O patrimônio cultural imaterial de Alagoas como estratégia de desenvolvimento territorial. Geosul, 33(69): 47-65.

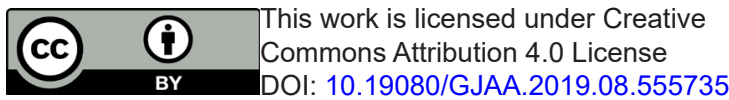

\section{Your next submission with Juniper Publishers will reach you the below assets}

- Quality Editorial service

- Swift Peer Review

- Reprints availability

- E-prints Service

- Manuscript Podcast for convenient understanding

- Global attainment for your research

- Manuscript accessibility in different formats

( Pdf, E-pub, Full Text, Audio)

- Unceasing customer service

Track the below URL for one-step submission https://juniperpublishers.com/online-submission.php 